\title{
Whipple's Disease Can be Diagnosed Using Paraffin-Embedded Specimens from the lleum Obtained During Ileocolonoscopy
}

We present a case of Whipple's disease diagnosed by biopsy of the terminal ileum. Light and electron microscopy revealed typical changes. Polymerase chain reaction (PCR) analysis performed on DNA from paraffin blocks demonstrated bacterial ribosomal DNA [1]. A 57-year-old previously healthy woman presented with malabsorption with 20 stools per day. Ileocolonoscopy and gastroscopy showed normal findings. Biopsies were obtained from the ileum, colon and duodenum. Light microscopy (Figure 1) suggested Whipple's disease and electron microscopy (Figure 2) demonstrated the bacteria. DNA from ileal paraffin blocks showed a PCR-product demonstrating $100 \%$ homology with the Tropheryma whippelii 16S rRNA gene. Intravenous cephalosporin was administered for 1 week followed by long-term treatment with trimethoprim $160 \mathrm{mg}$ and sulfamethoxazole $800 \mathrm{mg}$ b. i. d. Normalization of weight and stools ensued, and the patient was in excellent condition after 4 months. After 2 years of treatment biopsies showed no Tropheryma whippelii DNA detectable by PCR. Whipple's disease is lethal unless treated. The diagnosis has usually been based on duodenal biopsies. The value of

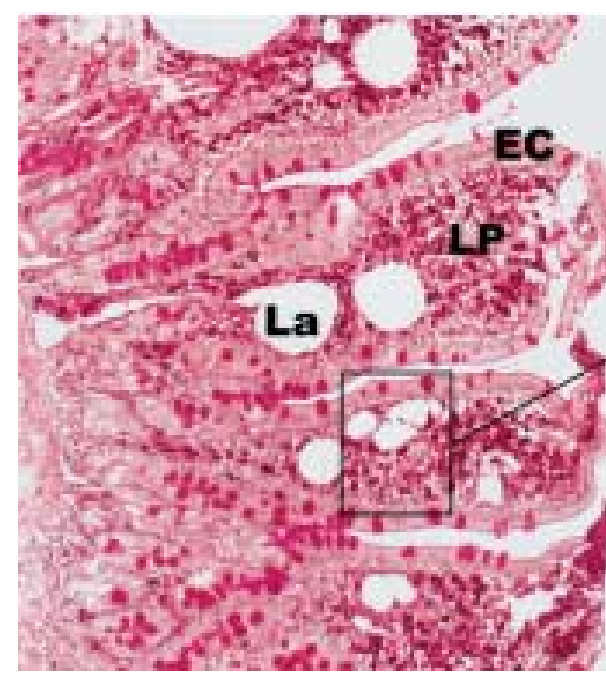

Figure 1 Light microscopy images of smallintestinal mucosa (diastase periodic acidSchiff [PAS] stain). Left: a low magnification overview (original magnification $\times 100$ ). Right: high magnification (original magnification $\times 400$ ) of rectangle in the left picture. ileoscopy in gastrointestinal diseases has been evaluated in a few studies [2]. It is the primary investigation for suspected ileal Crohn's disease and may reveal less frequently occurring diseases, such as villous atrophy, lymphoma, carcinoid, typhoid ulcer, NSAID-associated ulcer and tuberculosis. Our case adds Whipple's disease to this list. Whether biopsies from the terminal ileum are sufficient to discover all cases of Whipple's disease cannot be concluded either from this report or from the literature. On the other hand, since the lesion has been reported to be diffuse in the jejunum but patchy in the duodenum [3], duodenal biopsies might not reveal the diagnosis; thus, there is a rationale for performing ileal biopsies to make a diagnosis of Whipple's disease. Paraffin-embedded specimens can be used to provide DNA for diagnosis by PCR analysis, eliminating the need for a repeat endoscopy to obtain fresh tissue.

\section{K.-A. Ung 1, G. Havel ${ }^{2}$, B. Claesson ${ }^{3}$, \\ L. V. von Stedingk ${ }^{4}$, H.-S. Hanson ${ }^{4}$, G. Midhagen ${ }^{1}$}

${ }^{1}$ Department of Internal Medicine

2 Department of Pathology

${ }^{3}$ Department of Microbiology, Kärnsjukhuset, Skövde, Sweden

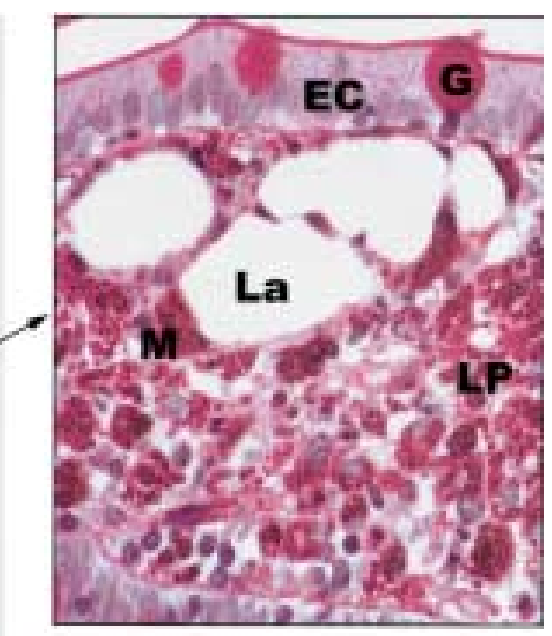

The lamina propria is expanded and packed with macrophages, which can be seen to be filled by red (diastase PAS-positive) granules. EC, epithelial resorptive cylinder cells; G, goblet cell; La, lacteal vessel; LP, lamina propria; $\mathrm{M}$, macrophage.
${ }^{4}$ Department of Clinical Microbiology, MTC, Karolinska Hospital, Stockholm, Sweden.

\section{References}

${ }^{1}$ Relman D. PCR-based detection of the uncultured bacillus of Whipple's disease In: Persing DH, Smith TF, Tenover FC, White TJ (eds). Diagnostic molecular microbiology, principles and applications. Washington DC: American Society for Microbiology 1993: 496-500

2 Bhasin DK, Goenka MK, Dhavan S et al. Diagnostic value of ileoscopy: a report from India. J Clin Gastroenterol 2000; 31: $144-146$

${ }^{3}$ Goldman H. Gastrointestinal mucosal biopsy. New York: Churchill Livingstone 1996: 305

Corresponding Author

K. A. Ung, M. D.

Department of Internal Medicine

Kärnsjukhuset

54185 Skövde, Sweden

Fax: $\quad$ +46-500-432539

E-mail: k.ung@telia.com

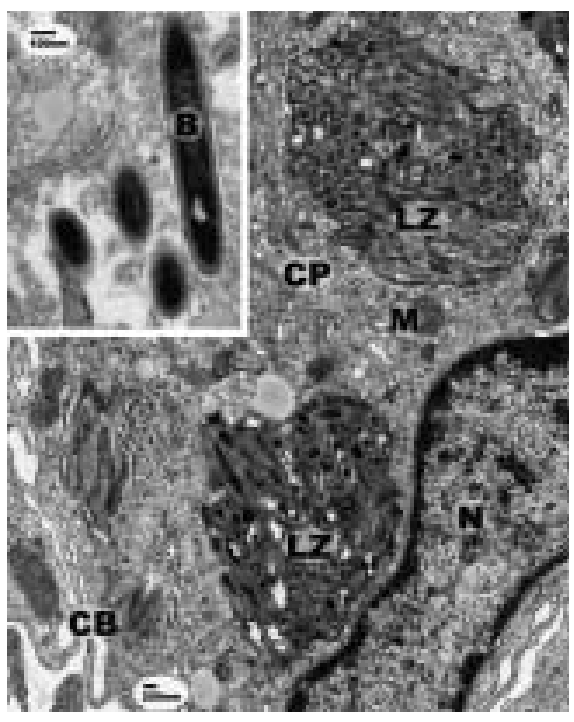

Figure 2 Electron microscopy images of a macrophage from the lamina propria. The larger photograph (original magnification $\times 20000$ ) contains lysozomes (LZ) with bacteria. $N$, nucleus; $C P$, cytoplasm; $M$, mitochondrion; CB, cell border. Inset: four bacteria (B) in the cytoplasm, in longitudinal and cross-sections (original magnification $\times 50000$ ). 